\title{
Assessment of Maternal and Fetal Outcomes in
}

\section{Adolescent and Non-Adolescent Pregnant Women}

\author{
Elçin Balcı ${ }^{1}$, Zehra İncedal Sonkaya ${ }^{2}$, Şemsinnur Göçer ${ }^{3^{*}}$ \\ ${ }^{1}$ Public Health Department of Erciyes University, Medicine School, Kayseri, Turkey \\ ${ }^{2}$ Elderly Care Department of Amasya University, Amasya, Turkey \\ ${ }^{3}$ Physical Therapy and Rehabilitation Department of Bozok University, Yozgat, Turkey
}

\begin{abstract}
The teenage pregnancy can result in unfavorable maternal and fetal outcomes. Here, we aimed to assess maternal and fetal outcomes in adolescent and non-adolescent pregnant women.

The study is a retrospective, comparative study. The study included all of 272 adolescent pregnant women (aged 13-19 years) who presented for delivery between 2010 and 2015 and 269 non-adolescent pregnant women (aged 20-49 years) selected from those presented for delivery during same period.

The gestational age at birth was significantly higher in patients aged $\leq 19$ years than those aged $\geq 20$ years.

The rate of infants with birth weight $>4000 \mathrm{~g}$, height and head circumference, and Apgar scores at minute 1 and 5 were significantly lower in patients aged $\leq 19$ years than those aged $\geq 20$ years.

Adolescent pregnancy is a major risk factor for many health and social outcomes.
\end{abstract}

Key Words: Adolescent, Perinatal outcomes, Pregnancy

\section{Introduction}

Adolescence includes period between 10 and 19 years of age, which comprises more than $20 \%$ of the world population. Annually, about 16 millions adolescent women give birth, accounting $11.0 \%$ of all births worldwide (1).

Sexual experience before marriage; thus, resultant pregnancies and induced abortion are more commonly encountered in developed countries while early marriage and resultant teenage pregnancies are more common due to cultural and traditional issues in developing countries such as Turkey. According to 2013 Turkey Demographic and Health Survey (TDHS-2013), 26.0\% of population was at adolescent age group in Turkey while $16.0 \%$ of adolescents aged 15-19 years were married with increased rate of begin childbearing by advancing age (2).

Teenage pregnancy limits many social rights of adolescent girls, mainly education, and should be considered as a violation of human rights and children's right in the first place (3). It confers heavy responsibilities to adolescents and prevents formal marriage (9). From social perspective, it is well-known that early marriage leads decreased self-confidence in adolescent individuals, making it difficult to create an original identity. Besides, problems more commonly seen in teenage pregnancy include interrupted education, isolation from social activities, divorce, separation, poverty, stress and depression (4). The teenage pregnancy can result in unfavorable maternal and fetal outcomes (5, 6). In adolescents, anemia, pregnancy-induced hypertension, lower weight gain during pregnancy, low birth weight infant and increased perinatal mortality can be seen during pregnancy $(7,8)$. Again, malnutrition, emotional stress and insufficient prenatal care are also more frequently observed in adolescents (5). These maternal disadvantages and immaturity can lead many problems in both fetuses at intrauterine period and newborns at postnatal period.

In this study, it was aimed to assess maternal and fetal outcomes in adolescent and non-adolescent pregnant women.

\section{Material and Method}

The study was conducted at Sabuncuoğlu Şerefeddin Teaching and Research Hospital of Amasya University. It is a retrospective, casecontrol study including 2 groups (adolescent and non-adolescent pregnant women). The study included all of 272 adolescent pregnant women (aged 13-19 years) who presented for delivery 
Balc1 et a1. / Adolescent and Non-Adolescent Pregnancy

Table 1. Relationship between sociodemographic characteristics and age groups

\begin{tabular}{|c|c|c|c|c|c|c|c|c|c|}
\hline & \multicolumn{6}{|c|}{ Age groups } & \multirow{2}{*}{\multicolumn{2}{|c|}{ Test }} \\
\hline & & \multicolumn{2}{|c|}{$\leq 19$ years } & \multicolumn{2}{|c|}{$\geq 20$ years } & \multicolumn{2}{|c|}{ Total } & & \\
\hline & & $\mathrm{n}$ & $\%$ & $\mathrm{n}$ & $\%$ & $\mathrm{n}$ & $\%$ & $\mathrm{X}^{2}$ & $\mathrm{p}$ \\
\hline \multirow{7}{*}{ Education level } & Illiterate & 7 & 2.6 & 0 & 0.0 & 7 & 1.3 & \multirow{7}{*}{343.111} & \multirow{7}{*}{0.0001} \\
\hline & Literate & 2 & .7 & 0 & 0.0 & 2 & .4 & & \\
\hline & Primary school & 80 & 29.4 & 5 & 1.9 & 85 & 15.7 & & \\
\hline & Secondary school & 153 & 56.3 & 48 & 17.8 & 201 & 37.2 & & \\
\hline & High school & 30 & 11.0 & 115 & 42.8 & 145 & 26.8 & & \\
\hline & College & 0 & 0.0 & 101 & 37.5 & 101 & 18.7 & & \\
\hline & Total & 272 & 100.0 & 269 & 100.0 & 541 & 100.0 & & \\
\hline \multirow{3}{*}{ Formal marriage } & Present & 218 & 80.1 & 266 & 98.9 & 484 & 89.5 & \multirow{3}{*}{50.377} & \multirow{3}{*}{0.0001} \\
\hline & Absent & 54 & 19.9 & 3 & 1.1 & 57 & 10.5 & & \\
\hline & Total & 272 & 100.0 & 269 & 100.0 & 541 & 100.0 & & \\
\hline \multirow{3}{*}{ Smoking } & Yes & 22 & 8.1 & 67 & 24.9 & 89 & 16.5 & \multirow{3}{*}{27.834} & \multirow{3}{*}{0.0001} \\
\hline & No & 250 & 91.9 & 202 & 75.1 & 452 & 83.5 & & \\
\hline & Total & 272 & 100.0 & 269 & 100.0 & 541 & 100.0 & & \\
\hline \multirow{4}{*}{ Mode of delivery } & Normal delivery & 164 & 60.3 & 132 & 49.1 & 296 & 54.7 & \multirow{4}{*}{18.467} & \multirow{4}{*}{0.0001} \\
\hline & Operative delivery & 13 & 4.8 & 2 & .7 & 15 & 2.8 & & \\
\hline & Cesarean section & 95 & 34.9 & 135 & 50.2 & 230 & 42.5 & & \\
\hline & Total & 272 & 100.0 & 269 & 100.0 & 541 & 100.0 & & \\
\hline \multirow{3}{*}{$\begin{array}{l}\text { Birth before } 36 \\
\text { weeks of gestation }\end{array}$} & Present & 23 & 8.5 & 18 & 6.7 & 41 & 7.6 & \multirow{3}{*}{0.601} & \multirow{3}{*}{0.438} \\
\hline & Absent & 249 & 91.5 & 251 & 93.3 & 500 & 92.4 & & \\
\hline & Total & 272 & 100.0 & 269 & 100.0 & 541 & 100.0 & & \\
\hline
\end{tabular}

between 2010 and 2015 and 269 non-adolescent pregnant women (aged 20-49 years) selected from those presented for delivery during same period.

In all pregnant women included, age, demographic data such as gestational age at birth, number of pregnancies, deliveries and abortions, educational level, presence of formal marriage, smoking habits; obstetric data such as mode of delivery, postpartum hematocrit levels, presence or absence of placental anomaly, premature rupture of membranes, intrauterine growth retardation (IUGR), oligohydramnios, preeclampsia and stillbirth; and neonatal characteristics such as birth weight, Apgar score at minute 1 and 5 were recorded by using a datasheet.

The normality of data was assessed by Shapiro Wilk's test. Independent $t$ test was used for intergroup comparisons. Chi-square test was used to determine relationship between categorical variables categorical variables between groups. Fisher's exact test was used in case of failure in 2x2 matrix. Pearson's chi square analysis was performed in $\mathrm{RxC}$ matrix via Monte Carlo simulation. A $p$ value $<0.05$ was considered as statistically significant.
A significant relation was found between educational level and age groups $(p<0.05)$. It was seen that $56.3 \%$ of patients aged $\leq 19$ years had secondary school degree while $42.8 \%$ of patients aged $\geq 20$ years had high school degree.

There was a significant relation between formal marriage status and age groups $(p<0.05)$. It was seen that $80.1 \%$ of the patients aged $\leq 19$ years and $98.9 \%$ of those aged $\geq 20$ years had formal marriage.

There was a significant relation between smoking and age groups $(p<0.05)$. It was found that $91.9 \%$ of patients aged $\leq 19$ years were non-smokers while this rate was $75.1 \%$ among those aged $\geq 20$ years.

A significant relation was found between mode of delivery and age groups. It was observed that $60.3 \%$ of patients aged $\leq 19$ years underwent normal delivery while $50.2 \%$ of those age $\geq 20$ years underwent cesarean section.

Although there was no significant difference between age groups, rate of birth before gestational week 36 was $8.5 \%$ in patients aged $\leq 19$ years and $6.7 \%$ in those aged $\geq 20$ years ( $>0.05$ ). 
Table 2. Relationship between obstetric parameters and age groups

\begin{tabular}{|c|c|c|c|c|c|c|c|c|}
\hline \multirow{2}{*}{\multicolumn{2}{|c|}{ Obstetric parameters }} & \multicolumn{2}{|c|}{$\mathrm{t}$ test } & \multirow[b]{2}{*}{ Median } & \multirow[b]{2}{*}{ Minimum } & \multirow[b]{2}{*}{ Maximum } & \multirow[b]{2}{*}{$\mathrm{t}$} & \multirow[b]{2}{*}{$\mathrm{p}$} \\
\hline & & $\mathrm{n}$ & Mean & & & & & \\
\hline \multirow{3}{*}{ Gestational week } & $\begin{array}{l}\leq 19 \\
\text { years }\end{array}$ & 272 & 39.13 & 40.00 & 33.00 & 42.00 & \multirow{3}{*}{8.287} & \multirow{3}{*}{0.0001} \\
\hline & $\begin{array}{l}\geq 20 \\
\text { years }\end{array}$ & 269 & 37.98 & 38.00 & 34.00 & 40.00 & & \\
\hline & Total & 541 & 38.56 & 39.00 & 33.00 & 42.00 & & \\
\hline \multirow{3}{*}{$\begin{array}{l}\text { Maternal hemoglobin } \\
\text { value }\end{array}$} & $\begin{array}{l}\leq 19 \\
\text { years }\end{array}$ & 272 & 11.21 & 11.20 & 7.50 & 17.00 & \multirow{3}{*}{2.935} & \multirow{3}{*}{0.003} \\
\hline & $\begin{array}{l}\geq 20 \\
\text { years }\end{array}$ & 269 & 10.88 & 11.00 & 8.40 & 12.60 & & \\
\hline & Total & 541 & 11.04 & 11.20 & 7.50 & 17.00 & & \\
\hline \multirow{3}{*}{ Birth weight } & $\begin{array}{l}\leq 19 \\
\text { years }\end{array}$ & 272 & 3193.57 & 3215.00 & 1740.00 & 4610.00 & \multirow{3}{*}{-2.505} & \multirow{3}{*}{0.013} \\
\hline & $\begin{array}{l}\geq 20 \\
\text { years }\end{array}$ & 269 & 3292.97 & 3260.00 & 2160.00 & 5300.00 & & \\
\hline & Total & 541 & 3242.99 & 3240.00 & 1740.00 & 5300.00 & & \\
\hline \multirow{3}{*}{ Birth weight } & $\begin{array}{l}\leq 19 \\
\text { years }\end{array}$ & 272 & 49.80 & 50.00 & 40.00 & 52.00 & \multirow{3}{*}{-2.549} & \multirow{3}{*}{0.011} \\
\hline & $\begin{array}{l}\geq 20 \\
\text { years }\end{array}$ & 269 & 50.05 & 50.00 & 40.00 & 54.00 & & \\
\hline & Total & 541 & 49.92 & 50.00 & 40.00 & 54.00 & & \\
\hline \multirow{3}{*}{ Head circumference } & $\begin{array}{l}\leq 19 \\
\text { years }\end{array}$ & 272 & 33.92 & 34.00 & 29.00 & 39.00 & \multirow{3}{*}{-8.178} & \multirow{3}{*}{0.0001} \\
\hline & $\begin{array}{l}\geq 20 \\
\text { years }\end{array}$ & 269 & 35.30 & 35.00 & 3.00 & 38.00 & & \\
\hline & Total & 541 & 34.60 & 35.00 & 3.00 & 39.00 & & \\
\hline \multirow{3}{*}{ Apgar score at minute 1} & $\begin{array}{l}\leq 19 \\
\text { years }\end{array}$ & 272 & 9.46 & 10.00 & 3.00 & 10.00 & \multirow{3}{*}{-2.714} & \multirow{3}{*}{0.007} \\
\hline & $\begin{array}{l}\geq 20 \\
\text { years }\end{array}$ & 269 & 9.73 & 10.00 & 2.00 & 10.00 & & \\
\hline & Total & 541 & 9.59 & 10.00 & 2.00 & 10.00 & & \\
\hline \multirow{3}{*}{ Apgar score at minute 5} & $\begin{array}{l}\leq 19 \\
\text { years }\end{array}$ & 272 & 9.82 & 10.00 & 5.00 & 10.00 & \multirow{3}{*}{-0.624} & \multirow{3}{*}{0.533} \\
\hline & $\begin{array}{l}\geq 20 \\
\text { years }\end{array}$ & 269 & 9.85 & 10.00 & 3.00 & 10.00 & & \\
\hline & Total & 541 & 9.83 & 10.00 & 3.00 & 10.00 & & \\
\hline
\end{tabular}

There was a significant difference in gestational age between groups $(\mathrm{p}<0.05)$. The gestational age was significantly higher in patients aged $\leq 19$ years. There was a significant difference in hemoglobin values during gestation between groups. The hemoglobin value was significantly higher in patients aged $\leq 19$ years.

There was a significant difference in birth weight among age groups $(\mathrm{p}<0.05)$. Birth weight was significantly lower among infants from patients aged $\leq 19$ years. Also, a significant difference was observed in birth height between age groups $(p<0.05)$. The birth height was significantly shorter in infants of patients aged $\leq 19$ years. There was significant difference in head circumference between groups as being significantly lower in infants from patients aged $\leq 19$ years.

There were significant differences in Apgar scores at minutes 1 and 5 between age groups $(\mathrm{p}<0.05)$. Both Apgar scores at minute 1 and 5 were significantly lower in infants of patients aged $\leq 19$ years. 
There was no significant correlation between birth weight $<2500 \mathrm{~g}$ and age groups.

Again, there was a significant relation between preeclampsia status and age groups. It was seen that $99.3 \%$ of patients aged $\leq 19$ years had no preeclampsia while this rate was $92.9 \%$ in those aged $\geq 20$ years.

No significant relation was observed between intrauterine growth retardation and age groups.

There was a significant correlation between presence of oligohydramnios and age group. No oligohydramnios was present in $99.6 \%$ of patients aged $\leq 19$ years and $93.7 \%$ of those $\geq$ aged 20 years.

No significant relation was found between presence of diabetes mellitus and age groups. There was no patient with diabetes mellitus among those aged $\leq 19$ years while $5.9 \%$ of patients aged $\geq 10$ years had diabetes mellitus.

There was a significant relation between birth weight $>4000 \mathrm{~g}$ and age groups. The rate of infants with birth weight $\geq 4000 \mathrm{~g}$ was $1.8 \%$ in patients aged $\leq 19$ years and $6.7 \%$ in those aged $\geq 20$ years.

A significant relation was detected between placental anomaly and age groups $(\mathrm{p}<0.05)$. There was placental anomaly in $0.7 \%$ of patients aged $\leq 19$ years and in $14.5 \%$ of patients aged $\geq 20$ years.

There was no significant correlation between presence of congenital anomaly and age groups.

\section{Discussion}

In our study, it was found that $56.3 \%$ of patients aged $\leq 19$ years had secondary school degree while $42.8 \%$ of patients aged $\geq 20$ years had high school degree and that educational level was significantly lower in patients aged $\leq 19$ years when compared to those aged $\geq 20$ years (Table 1 ). Again, rate of formal marriage was significantly lower in patients aged $\leq 19$ years than those in patients aged $\geq 20$ years (Table 1). In a study by Melekoğlu et al., it was found that $52.5 \%$ of adolescent women had no formal marriage (1). According to TDHS-2013, $17.0 \%$ of women with no formal education or no primary school degree had started childbearing at adolescent period while this rate was $8.0 \%$ among women having at least primary degree (2). Teenage pregnancies are more commonly seen in those with low educational level and pregnancy hinders education and participation to work in young mothers and makes them dependent in economic manner (9).
In our study, it was observed that $60.3 \%$ of patients aged $\leq 19$ years underwent normal delivery while $50.2 \%$ of those age $\geq 20$ years underwent cesarean section (Table 1). It is known that cesarean rate is lower in pregnancies at adolescent period when compared to other pregnancies (1013). In the study by İnalöz et al., it was found that normal delivery rate was higher in adolescents (14). Our results are in agreement with literature. It may be thought that economic status and presence of social insurance are also effective for provision of cesarean section.

There was a significant difference in gestational age at birth and age groups with higher gestational age at birth in patients aged $\leq 19$ years than those aged $\geq 20$ years (Table 2 ). On contrary, İnalöz et al. reported that gestational age at birth was approximately one week younger in teenage pregnancies than other pregnancies (14). It is known that adolescent pregnancy is an independent risk factor for preterm delivery (15, 16). In the logistic regression analysis of 54,447 deliveries, it was shown that preterm delivery risk was 3- or 4-times higher among adolescent pregnant women when compared to those aged 20-30 years (15). This outcome is inconsistent with literature. This may be due to fact that there are multiple factors involved in preterm delivery and that adolescent pregnancy is only one of these factors.

In our study, there was significant difference in maternal hemoglobin values and age groups with higher maternal hemoglobin values in pregnant women aged $\leq 19$ years (Table 2 ). In the literature, it is suggested that anemia is a condition that may complicated pregnancy in adolescents. The maternal anemia incidence has been reported to reach up to $76 \%$ in adolescent pregnant women in several studies (17). As adolescent individuals does not complete their own development and require iron and other vitamin and minerals for development, additional demand caused by pregnancy makes the condition more severe. In addition to iron, folic acid, calcium, magnesium, vitamin $\mathrm{E}$ and $\mathrm{B} 12$ intake is also lower in adolescents, resulting in deficiencies of these vitamins and minerals in adolescents $(18,19)$. In the study on 945 adolescent pregnant women, Keskinoğlu et al. found that anemia incidence was higher among adolescent pregnant women (38.5\%) than adult population (11). In our study, hemoglobin value was found to be higher in 
Table 3. Results of Chi-square test differences between age groups regarding variables evaluated

\begin{tabular}{|c|c|c|c|c|c|c|c|c|c|}
\hline & & \multicolumn{6}{|c|}{ Age groups } & \multirow{2}{*}{\multicolumn{2}{|c|}{ Test }} \\
\hline & & \multicolumn{2}{|c|}{$\leq 19$ years } & \multicolumn{2}{|c|}{$\geq 20$ years } & \multicolumn{2}{|c|}{ Total } & & \\
\hline & & $\mathrm{n}$ & $\%$ & $\mathrm{n}$ & $\%$ & $\mathrm{n}$ & $\%$ & $\mathrm{X}^{2}$ & $\mathrm{p}$ \\
\hline \multirow{3}{*}{ Birth weight $<2500 \mathrm{~g}$} & Yes & 18 & 6.6 & 12 & 4.5 & 30 & 5.5 & \multirow{3}{*}{1.201} & \multirow{3}{*}{0.273} \\
\hline & No & 254 & 93.4 & 257 & 95.5 & 511 & 94.5 & & \\
\hline & Total & 272 & 100.0 & 269 & 100.0 & 541 & 100.0 & & \\
\hline \multirow{4}{*}{ Preeclampsia } & No & 270 & 99.3 & 250 & 92.9 & 520 & 96.1 & \multirow{4}{*}{21.924} & \multirow{4}{*}{$\begin{array}{c}0.000 \\
1\end{array}$} \\
\hline & Mild & 1 & 0.4 & 19 & 7.1 & 20 & 3.7 & & \\
\hline & Severe & 1 & 0.4 & 0 & 0.0 & 1 & 0.2 & & \\
\hline & Total & 272 & 100.0 & 269 & 100.0 & 541 & 100.0 & & \\
\hline \multirow{3}{*}{$\begin{array}{l}\text { Intrauterine growth } \\
\text { retardation }\end{array}$} & Yes & 6 & 2.2 & 12 & 4.5 & 18 & 3.3 & \multirow{3}{*}{2.138} & \multirow{3}{*}{0.144} \\
\hline & No & 266 & 97.8 & 257 & 95.5 & 523 & 96.7 & & \\
\hline & Total & 272 & 100.0 & 269 & 100.0 & 541 & 100.0 & & \\
\hline \multirow{3}{*}{ Oligohydramnios } & Yes & 1 & 0.4 & 17 & 6.3 & 18 & 3.3 & \multirow{3}{*}{14.896} & \multirow{3}{*}{$\begin{array}{c}0.000 \\
1\end{array}$} \\
\hline & No & 271 & 99.6 & 252 & 93.7 & 523 & 96.7 & & \\
\hline & Total & 272 & 100.0 & 269 & 100.0 & 541 & 100.0 & & \\
\hline \multirow{3}{*}{ Diabetes mellitus } & Yes & 0 & 0.0 & 16 & 5.9 & 16 & 3.0 & \multirow{3}{*}{16.671} & \multirow{3}{*}{$\begin{array}{c}0.000 \\
1\end{array}$} \\
\hline & No & 272 & 100.0 & 253 & 94.1 & 525 & 97.0 & & \\
\hline & Total & 272 & 100.0 & 269 & 100.0 & 541 & 100.0 & & \\
\hline \multirow{3}{*}{ Birth weight $>4000 \mathrm{~g}$} & Yes & 5 & 1.8 & 18 & 6.7 & 23 & 4.3 & \multirow{3}{*}{7.826} & \multirow{3}{*}{0.005} \\
\hline & No & 267 & 98.2 & 251 & 93.3 & 518 & 95.7 & & \\
\hline & Total & 272 & 100.0 & 269 & 100.0 & 541 & 100.0 & & \\
\hline \multirow{3}{*}{ Placental anomaly } & Yes & 2 & 0.7 & 39 & 14.5 & 41 & 7.6 & \multirow{3}{*}{36.575} & \multirow{3}{*}{$\begin{array}{c}0.000 \\
1\end{array}$} \\
\hline & No & 270 & 99.3 & 230 & 85.5 & 500 & 92.4 & & \\
\hline & Total & 272 & 100.0 & 269 & 100.0 & 541 & 100.0 & & \\
\hline \multirow{3}{*}{ Congenital anomaly } & Yes & 0 & 0.0 & 1 & 0.4 & 1 & 0.2 & \multirow{3}{*}{$\mathrm{f}$} & \multirow{3}{*}{0.497} \\
\hline & No & 272 & 100.0 & 268 & 99.6 & 540 & 99.8 & & \\
\hline & Total & 272 & 100.0 & 269 & 100.0 & 541 & 100.0 & & \\
\hline
\end{tabular}

adolescents on contrary to literature.

In our study, rate of infants with birth weight $>4000 \mathrm{~g}$ was $1.8 \%$ in patients aged $\leq 19$ years whereas $6.7 \%$ in those aged $\geq 20$ years, indicating a significant difference (Table 3). In many studies, it was found that there is a relationship between pregnancy at adolescence period and low birth weight (12-20). Inalöz et al. reported similar results (14). In a study on 775 adolescent pregnant women from Central Africa, Florian et al. found that rate of low birth weight was higher when compared to controls (21). It is also known that teenage pregnancy is an independent risk factor for preterm birth $(15,16)$. It was shown that preterm delivery risk was 3 - or 4 -folds higher among adolescent pregnant women when compared to those aged 20-30 years (15). Also, it is known that rate of low birth weight infant is increased due to prematurity in teenage pregnancies $(17,22)$. In a retrospective study including 16,857 pregnancies, it was reported relative risk for low birth weight was increased by 1.7 folds in adolescent pregnant women (23). Again, Meydanl et al. reported that preterm birth and low birth weight rates were higher in adolescence age group than normal population (24).

In our study, both height and head circumference at birth were significantly lower in patients aged $\leq 19$ years when compared to those aged $\geq 20$ years (Table 3). It has been reported that adolescent pregnant women do not use prenatal care effectively; that pregnancy is more commonly completed without antenatal care; thus, maternal and fetal problems can occur (25). On the other hand, in some studies, it was reported that younger maternal age is not the only factor accounting for unfavorable effects on infant and mother and other social and biological 
disadvantages associated to adolescents are also involved $(25,26)$.

In our study, Apgar scores at minute 1 and 5 were significantly lower in infants from mothers aged $\leq 19$ years (Table 3 ). In the study by Taner et al., no significant difference was reported while results similar to our study were reported by Ayyıldiz et al. (28). Prolonged labor, also known as failure to progression, is very commonly seen in first delivery in adolescents as pelvic development is incomplete in these patients. This may be due to small pelvis or inappropriate fetal presentation (25). However, interventions to facilitate labor include forceps and vacuum during vaginal delivery. Labor requires more intervention in adolescent pregnant women (29).

In our study, preeclampsia was lacking in $99.3 \%$ of patients aged $\leq 19$ years, which was significantly higher than those aged $\geq 20$ years (Table 3 ). In the literature, it has been reported that preeclampsia incidence was $7.5 \%$ of all pregnancies (30); that eclampsia incidence varies according to maternal age distribution and proportion of primipar pregnancies in the study population (31); that it often involves young, nullipar pregnant women and risk for eclampsia is higher due to underlying hypertension in pregnancies at older age; and that preeclampsia and eclampsia are more commonly seen among adolescent pregnant women when compared to those aged $\geq 20$ years (12). Again, in the study by İnalöz et al., it was suggested that eclampsia incidence was higher among adolescents. Our results are inconsistent with literature.

In case of disrupted fetoplacental perfusion such as intrauterine growth retardation, fetal urine production is decreased, resulting in insufficient amniotic fluid and oligohydramnios (33). The oligohydramnios rate was $0.4 \%$ in patients aged $\leq 19$ years whereas $6.3 \%$ in those aged $\geq 20$ years in our study (Table 3 ). It was significantly higher in patients aged $\geq 20$ years. In a previous study, it was reported that oligohydramnios was seen in $12.0 \%$ of adolescent pregnant women whereas $5.0 \%$ of normal pregnancies, indicating no significant difference between adolescent and non-adolescent pregnant women (28). Our result may be due to fact that there are many factors causing oligohydramnios and mechanisms related to amniotic fluid in addition to age.

The rate of diabetes was $5.9 \%$ in patients aged $\geq 20$ years while there was no case with diabetes mellitus among those aged $\leq 19$ years, indicating significantly higher DM rate in patients aged $\geq 20$ years (Table 3 ).
Gestational diabetes mellitus is rarer among young women. Pancreatic B cell function and insulin sensitivity is decreased by advancing age. In older women, predisposition to diabetes mellitus can be linked to insufficient $B$ cell response and increased insulin resistance (34). This finding may be explained by predisposition to diabetes mellitus via increased insulin resistance in older age.

In our study, placental anomaly was seen in $0.7 \%$ of patients aged $\leq 19$ years whereas it was found in $14.5 \%$ of patients aged $\geq 20$ years, indicating a significant difference (Table 3). In a previous study, it was reported that placental anomaly was detected in $2.0 \%$ of adolescent pregnant women and in $4.2 \%$ of non-adolescent pregnant women but there was no significant difference between groups (35). Our results are inconsistent with literature. In a study by Taner et al., it was found that placental anomaly incidence was comparable among adolescents and adults without no significant difference (27). This may be due to fact that several risk factors are involved in development of placental anomalies in addition to pregnancy at adolescence period.

The incidences of preeclampsia, diabetes mellitus, placental anomaly and oligohydramnios were higher in non-adolescent pregnant women. The infants delivered by adolescent pregnant women had shorter height and smaller head circumference, lower birth weight, and lower Apgar scores at minute 1 and 5. These are among risk factors that may affect on infant health and increase mortality in infants. Thus, pregnancy at adolescence period should be prevented and it must be followed closely for maternal and fetal adverse outcomes.

Authors declared that no competing interest exists in planning, execution and completion phases of the study. No funds were granted to the study from any organization.

\section{References}

1. http://apps.who.int/gb/ebwha/pdf_files/WHA6 5-REC3/A65_REC3-en.pdf. Date of access:10.10.2017.

2. Adölesan Doğurganlık ve Annelik. Türkiye Nüfus ve Sağlık Araştırması, 2013: 72-73.

3. Treffers PE. Teenage pregnancy, aworldwide problem. Nederlands Tijdschrift Voor Geneeskunde 2003; 147: 2320-2325.

4. World Health Organization. What are the most effective strategies for reducing the rate of teenage pregnancies? Geneva; 2006.

5. Chandra PC, Schiavello HJ, Ravi B, Weinstein AG, Hook FB. Pregnancy outcomes in urban

East J Med Volume:25, Number:1, January-March/2020 
teenagers. Int J Gynaecol Obstet 2002; 79: 117 122.

6. Stevens-Simon C, McAnarney ER. Adolescent pregnancy. Gestational weight gain and maternal and infant outcomes. Am J Dis Child 1992; 146: 1359-1364.

7. Melekoğlu R, Evrüke C, Kafadar T, Misırlıŏ̆lu S, Büyükkurt S, Özgünen TF. Adölesan Gebeliklerin Perinatal Sonuçları. Turk Soc Obstet Gynecol 2013; 10: 213-219.

8. Öner S, Yapıcı G. Adölesan gebeliklere bakış. Türkiye Halk Sağlığı Dergisi 2010; 8: 30-39.

9. Keskinoğlu P, Bilgiç N, Pıçakçı EM. Perinatal outcomes and risk factors of Turkish adolesccent mothers. J Pediatr Adolesc Gynecol 2007; 20: 1924.

10. Güzel Aİ, Tokmak A, Engin Üstün Y. The Journal of Gynecology - Obstetrics and Neonatology 2016; 13: 28-31.

11. İnalöz EY, Metin İngeç $M$, Topdağı Yılmaz EP. Bölgemizdeki Adölesan Gebeliklerin Maternal Ve Perinatal Sonuçlar Üzerine Etkilerinin Değerlendirilmesi. Mustafa Kemal Üniversitesi Tıp Dergisi 2017; 8: 6-14.

12. DuPlessis HM, Bell R, Richards T. Adolescent pregnancy: understanding the impact of age and race on outcomes. J Adolesc Health 1997; 20: 187-197.

13. Van Enk WJ, Gorissen WH, van Enk A. Teenage pregnancy and ethnicity in The Netherlands: frequency and obstetric outcome. Eur J Contracpt Reprod Health Care 2000; 5: 77-84.

14. Chahande MS, Jadho AR, Wadhva SK, Udhade S. Study of some epidemiological factors in teenage pregnancy hospital based case comparison study. Indian J Community Med 2002; 27: 106-109.

15. Moran VH. A systematic review of dietary assessments of pregnant adolescents in industrialised countries. Br J Nutr 2007; 97 : 411-425.

16. Pathak P, Singh P, Kapil U, Raghuvanshi RS. Prevalence of iron, vitamin $A$, and iodine deficiencies amongst adolescent pregnant mothers. Indian J Pediatr 2003; 70: 299-301.

17. Aruda MM, Waddicor K, Frese L, et al. Early pregnancy in adolescents: diagnosis, assessment, options counseling, and referral. J Pediatr Health Care 2010; 24: 4-13.

18. Demirgöz M, Canbulat N. Adölesan gebelik. Turkiye Klinikleri J med Sci 2008; 28.

19. Kurth F, Bélard S, Mombo-Ngoma G, et al. Adolescence as risk factor for adverse pregnancy outcome in Central Africa-a crosssectional study. PLoS One 2010; 5: 14367.

20. Sarkar CS, Girl AK, Sarkar B. Outcome of teenage pregnancy and labour: A retrospective study. J Ind Med Assoc 1991; 89: 197-199.

21. Miller HS, Lesser KB, Reed KL. Adolescence and very low birth weight infants: a disproportionate association. Obstet Gynecol 1996; 87: 83-88.

22. Meydanlı MM, Çalışkan E, Ecemiş T, et al. Adölesanlarda Gebelik Sonuçlarının Değerlendirilmesi. Türkiye Klinikleri Journal of Gynecology and Obstetrics 2000; 10: 98-103.

23. Taner CE, Kırmızı DA, İriş A. ark. Adölesan Gebeliklerin Sonuçları. Göztepe Tip Dergisi 2012; 27: 6-10.

24. Ayyıldız T, Topan A, Öztürk Ö, Kulakçı H. Adölesan Gebeliklerin Anne ve Bebeğe Yönelik Obstetrik Sonuçlar Açısından Değerlendirilmesi. Dokuz Eylül Üniversitesi Hemşirelik Fakültesi Elektronik Dergisi 2015, 8: 61-66.

25. Ağaçayak E, Alan B, Turgut A, et al. Adölesan Gebelerin Maternal Ve Fetal Sonuçlarının Değerlendirilmesi. Dicle Tıp Dergisi/2016; 43: 344-350. 